\title{
Influence of activating Fcgamma receptors on osteoclast differentiation and bone metabolism
}

\author{
Michaela Seeling ${ }^{1 *}$, Jan Peter Tuckermann ${ }^{2}$, Jean Pierre David ${ }^{3}$, Georg Schett ${ }^{4}$, Falk Nimmerjahn ${ }^{1}$ \\ From 7th European Workshop on Immune-Mediated Inflammatory Diseases \\ Noordwijk aan Zee, the Netherlands. 28-30 November 2012
}

\section{Background}

Patients with Rheumatoid Arthritis suffering from chronic inflammation of the joints have a higher risk of developing osteoporosis. One hallmark of this inflammatory process is an increased production of autoantibodies. It is unclear, whether the autoantibodies can act directly on cells of the bone metabolism via Fcgamma receptors (Fc $\gamma$ Rs). Thus, the aim of this project is to analyze the influence of the activating FcyR expression on osteoclasts, the bone-resorbing cells, and the bone metabolism in vitro and in vivo by comparison of $\mathrm{C} 57 \mathrm{Bl} / 6$ and several Fc $\gamma \mathrm{R}$ knockout mice.

\section{Materials and methods}

FACS analysis of in vitro cultivated osteoclasts was performed to confirm the expression of Fc $\gamma$ Rs. Their influence on the differentiation of bone marrow cells to mature osteoclasts was analyzed by crosslinking the receptors during the cultivation. To simulate a rheumatoid arthritis in vivo the KRN-serum transfer model was used. Assessment of the inflammatory effects was performed by serological, structural and histomorphomic analysis.

\section{Results}

FACS analysis showed that in vitro cultivated osteoclasts upregulated the activating Fc $\gamma$ Rs during differentiation. The maturation process of osteoclasts was positively influenced upon crosslinking of the Fc $\gamma \mathrm{RI}$ and IV in vitro. In healthy mice and in mice suffering from rheumatoid arthritis different effects of the activating Fc $\gamma$ Rs was observed. Also, osteoclasts in healthy Fc $\gamma$ RIV knockout mice tended to be smaller. During a rheumatoid arthritis the loss of the Fc $\gamma R$ I and IV protected from inflammatory bone loss, although apparently by different mechanisms.

'Dept. of Biology, University Erlangen-Nuremberg, Erlangen, Germany Full list of author information is available at the end of the article

\section{Conclusions}

Our findings show that autoantibodies, which occur in increased amounts during the chronical inflammation of a rheumatoid arthritis, can have a direct effect on the boneresorbing osteoclasts via binding on Fc $\gamma$ Rs expressed on their surface.

\section{Author details}

${ }^{1}$ Dept. of Biology, University Erlangen-Nuremberg, Erlangen, Germany. ${ }^{2}$ Institute of General Zoology and Endocrinology, University of UIm, UIm, Germany. ${ }^{3}$ Dept. of Osteology and Biomechanics, University Medical Center Hamburg-Eppendorf, Hamburg, Germany. ${ }^{4}$ Dept. of Internal Medicine 3, University of Erlangen-Nuremberg, Erlangen, Germany.

Published: 28 November 2012

\section{doi:10.1186/1479-5876-10-S3-P24}

Cite this article as: Seeling et al:: Influence of activating Fcgamma receptors on osteoclast differentiation and bone metabolism. Journal of Translational Medicine 2012 10(Suppl 3):P24.

\section{Submit your next manuscript to BioMed Central and take full advantage of: \\ - Convenient online submission \\ - Thorough peer review \\ - No space constraints or color figure charges \\ - Immediate publication on acceptance \\ - Inclusion in PubMed, CAS, Scopus and Google Scholar \\ - Research which is freely available for redistribution

